\title{
Estimating spatially distributed monthly evapotranspiration rates by linear transformations of MODIS daytime land surface temperature data
}

\author{
J. Szilagyi ${ }^{1,2}$ and J. Jozsa ${ }^{1}$ \\ ${ }^{1}$ Budapest University of Technology and Economics, 1111 Muegyetem Rkp. 3-9, Budapest, Hungary \\ ${ }^{2}$ University of Nebraska-Lincoln, Holdrege St. 3310, Lincoln, NE 68583, USA
}

Received: 2 February 2009 - Published in Hydrol. Earth Syst. Sci. Discuss.: 2 March 2009

Revised: 4 May 2009 - Accepted: 15 May 2009 - Published: 20 May 2009

\begin{abstract}
Under simplifying conditions catchment-scale vapor pressure at the drying land surface can be calculated as a function of its watershed-representative temperature $\left(<T_{S}>\right)$ by the wet-surface equation (WSE, similar to the wet-bulb equation in meteorology for calculating the dry-bulb thermometer vapor pressure) of the Complementary Relationship of evaporation. The corresponding watershed ET rate, $<\mathrm{ET}>$, is obtained from the Bowen ratio with the help of air temperature, humidity and percent possible sunshine data. The resulting $\left(<T_{s}>,<\mathrm{ET}>\right)$ pair together with the wet-environment surface temperature $\left(<T_{w s}>\right)$ and ET rate $\left(\mathrm{ET}_{w}\right)$, obtained by the Priestley-Taylor equation, define a linear transformation on a monthly basis by which spatially distributed ET rates can be estimated as a sole function of MODIS daytime land surface temperature, $T_{s}$, values within the watershed. The linear transformation preserves the mean which is highly desirable. $\left\langle T_{w s}\right\rangle$, in the lack of significant open water surfaces within the study watershed (Elkhorn, Nebraska), was obtained as the mean of the smallest MODIS $T_{s}$ values each month. The resulting period-averaged (20002007) catchment-scale ET rate of $624 \mathrm{~mm} / \mathrm{yr}$ is very close to the water-balance derived ET rate of about $617 \mathrm{~mm} / \mathrm{yr}$. The latter is a somewhat uncertain value due to the effects of (a) observed groundwater depletion of about $1 \mathrm{~m}$ over the study period caused by extensive irrigation, and; (b) the uncertain rate of net regional groundwater supply toward the watershed. The spatially distributed ET rates correspond well with soil/aquifer properties and the resulting land use type (i.e. rangeland versus center-pivot irrigated crops).
\end{abstract}

Correspondence to: J. Szilagyi

(jszilagyi1@unl.edu)

\section{Introduction}

Evapotranspiration plays a central role in hydrologic and ecological modeling since it is a very effective vehicle for mass and energy (due to the high latent heat of vaporization value of water) transfer between the land/vegetation surface and the ambient atmosphere, and thus the energy and mass-balances of the involved surface cannot be closed without. Recently there has been a rapid progress in the development of spatially distributed evapotranspiration (ET) estimation algorithms using remotely sensed data. For a review of the current approaches see Gowda et al. (2008) or Courault et al. (2005). Common to all these approaches is the necessity to calibrate the varying number of parameters inherent in them. The same is true of all distributed hydrologic models, where often the relatively large number of parameters may lead to the well-documented phenomenon of over-parameterization leading to equifinality of the parameter values, meaning that a wide selection of parameter values result in almost identical model outputs. Consequently any new ET estimation algorithm that is able to reduce the number of parameters it requires or itself is calibration-free, such as our proposed method below, may prove to be useful in distributed watershed modeling and certainly worthy of further considerations in our opinion.

Szilagyi and Jozsa (2009a) recently published an ET estimation method based on an analytical solution of the coupled 2-D turbulent heat and vapor transport equations written for a moisture discontinuity at the surface (Laikhtman, 1964; Yeh and Brutsaert, 1971). Under a temporally constant energy term, $Q_{n}$ (from here on expressed in water-depth equivalent $\left[\mathrm{LT}^{-1}\right]$ ) available for sensible and latent heat fluxes at the surface as well as unchanging profiles of wind and

Published by Copernicus Publications on behalf of the European Geosciences Union. 
turbulent diffusivity for both drying and a constantly wet homogeneous land surface, the analytical solutions for the temperature $T_{s}[\mathrm{~K}]$ and vapor pressure $e_{s}\left[\mathrm{ML}^{-1} T^{-2}\right]$ terms at the drying surface can be combined into what Szilagyi and Jozsa (2009a) termed as the wet-surface equation (WSE)

$e_{s}-e_{w s}=\gamma\left(T_{w s}-T_{s}\right)$

after its identical form applied in meteorology to calculate the vapor pressure at the dry-bulb thermometer from measuring the wet-bulb temperature and which is called the wet-bulb equation. Here $T_{w s}$ and $e_{w s}$ are temperature and (saturated) vapor pressure at the wet surface, and $\gamma$ $\left[\mathrm{ML}^{-1} T^{-2} \mathrm{~K}^{-1}\right]$ the psychrometric constant. By knowing the temperature of the drying and the wet land surface the typically unknown value of the vapor pressure at the nonsaturated, drying surface can be obtained from Eq. 1. The method is based on the assumption that the land-air system is in a dynamic equilibrium, meaning that air humidity is influenced predominantly by the moisture condition of the land surface (under the given $Q_{n}$ and atmospheric profiles) and any external latent or sensible heat transfer to the area is negligible. Obviously this tenet is ever more true with the extent of the area growing, therefore the ET rate $\left[\mathrm{LT}^{-1}\right]$ the method yields with a constant $Q_{n}$ as

$\mathrm{ET}=Q_{n}(\mathrm{Bo}+1)^{-1}$

from the definition of the Bowen ratio Bo [-], can be considered as a regional or watershed-representative value.

For the summer-fall season (June-November) of the 2000-2006 period Szilagyi and Jozsa (2009a) compared the WSE-derived (i.e. Eqs. 1 and 2) monthly ET rates using 8-day composited Moderate Resolution Imaging Spectroradiometer (MODIS) daytime land surface temperature data averaged over the month with similar estimates of Morton's WREVAP program $(1983,1985)$ for five rectangular regions across the US and obtained a very high correlation not only on a monthly but also on an annual basis (i.e. $R^{2}=0.95$ ) between the ET estimates of the two methods. This however is not surprising because both approaches are based on the Complementary Relationship (CR) of evaporation (Bouchet, 1963). The CR, as formulated by Brutsaert and Stricker (1979) in their Advection Aridity (AA) model, is based on the assumption that under minimal energy advection and a constant $Q_{n}$ term the increase in the sensible heat over the drying land is fully transferred into potential evapotranspiration (PET), the latter expressed by the Penman equation (1948). Note that it is the same as saying that $Q_{n}$ is constant at both the drying and the constantly wet surface, since then the sensible heat transferred from the drying and hotter surface over the cooler wet patch must fully convert into latent heat in order to leave $Q_{n}$ intact there too. Thus the mean latent heat flux from the wet patch, having a fetch compatible with the Penman equation, will increase by the same magnitude as the sensible heat flux does over the drying and warming surface. For a more detailed discussion of this energy exchange, see Szilagyi and Jozsa (2009b). Note that while the AA and WREVAP models require the specification of the potential ET rate and also a so-called reference evaporation rate, $\mathrm{ET}_{w}$, traditionally chosen to be defined by the Priestley-Taylor (1972) equation in order to obtain the actual drying environment ET as $2 \mathrm{ET}_{w}-\mathrm{PET}$ (Brutsaert and Stricker, 1979), the WSE-based does not. Instead the latter requires the temperature at the drying and the wet surface. Both WREVAP and the WSE-based ET calculation approaches require air temperature and humidity as well as net radiation at the surface which can be practically taken as $Q_{n}$ for averaging time periods equal or longer than a day. Additionally, the AA model also needs wind measurements for its Penman equation.

Below our WSE-based ET estimation approach is extended to disaggregate the watershed-representative ET values into spatially distributed values over the roughly $1-\mathrm{km}$ resolution MODIS data grid via a time-dependent linear transformation of the $T_{S}$ cell values.

\section{Model description}

The Complementary Relationship (CR) of evaporation requires a dynamic equilibrium to be attained between the surface moisture status and the ambient air so that air humidity is predominantly controlled by the soil moisture. Since any passing weather front can tip this balance, Morton (1983, 1985) suggested not to apply the CR for periods shorter than about a week, unless the climate is such that weather fronts are absent in certain seasons or the whole of the year. See the application of the CR under the latter conditions for subdaily periods with adjustments to the changing energy available at the surface by Parlange and Katul (1992). We chose a monthly time-step for our calculations because (a) most watershed models employ the same time-step; (b) by averaging over a longer period assures that the alternating processes of drying and rewetting of the land occur in a larger number expected to yield an overall mean behavior of the land-atmosphere system according to Eq. 1 and (c) the possibility of a cloud-corrupted mean monthly cell value of $T_{S}$ is dramatically reduced if the cell value is averaged over the month in such a way that any suspicious value out of the 3-4 8-day composited MODIS daytime values within the month is left out from the averaging.

The WSE-based ET estimation model (Szilagyi and Jozsa, 2009a) employs the Bowen ratio in Eq. (2) to calculate the watershed representative ET value, $<\mathrm{ET}>$, from the watershed-representative surface temperature, $\left\langle T_{s}>\right.$ (i.e. the mean monthly $T_{s}$ cell values averaged over the watershed) and surface water vapor value $\left\langle e_{s}\right\rangle$ (obtained from Eq. 1 evaluated by $<T_{s}>$ ) plus the corresponding air temperature and water vapor value at a given elevation (typically $2 \mathrm{~m}$ ) 
from the ground. Since ET predominantly takes place during the day, the Bowen ratio must be evaluated with daytime values. The daytime mean air temperature, $T_{d t}$, can be calculated from the typically available daily mean value $T_{d}$ as $T_{d t}=T_{d}+k\left(T_{\max }-T_{d}\right)$, where $T_{\max }$ is the reported mean daily maximum temperature of the month, and $k[-]$ is an adjustment factor, a function of latitude $(\Phi)$ and season.

To determine $k$, first the length of the daytime (in radian) is calculated as twice the sunset angle, $\omega$ (radian, relative to noon). The latter is defined as $\omega=\operatorname{arc} \cos [-\tan (\Phi) \tan (\delta)]$ with $\delta=0.4093 \sin (2 \pi J / 365-1.405)$ where $J$ is the Julian date of the middle day of the month (e.g. Maidment, 1993). Considering the daily temperature signal $(T)$ sinusoid with an amplitude of $A\left(=T_{\max }-T_{d}\right)$ and peak around 3 p.m., it can be expressed as $T=A \sin (t-3 \pi / 4)$ with the time of the day, $t$, given in radian. The value of $k$ then results as the mean of this signal (i.e. its integral divided by the integration interval) over the daytime period of $(\pi-\omega, \pi+\omega)$ divided by A.

The daytime air vapor pressure, $e_{d t}$, values for the Bowen ratio were obtained from the mean, $\mathrm{RH}_{d t}[-]$, of the reported (typically at 6 a.m., noon, and 6 p.m.) daytime relative humidity values multiplied by the saturated vapor pressure at $T_{d t}$. Note that (a) no such transformations were necessary for the surface values since they are daytime values already; (b) $\mathrm{RH}_{d t}$ is typically very close to the daily mean relative humidity value, so in the lack of several measurements during the day, the latter, most frequently available average value can be employed.

By inserting the daytime values into Eq. (2) the monthly watershed representative ET rate becomes (Szilagyi and Jozsa, 2009a)

$<\mathrm{ET}>=Q_{n}\left[1+\gamma\left(<T_{s}>-T_{d t}\right)\left(<e_{s}>-e_{d t}\right)^{-1}\right]^{-1}$.

$Q_{n}$ was calculated by Morton's (1985) WREVAP program requiring only percent possible sunshine as input (the program also accepts global incident radiation in lieu of sunshine data) additional to air temperature and humidity measurements. This FORTRAN source code is hard to get by, therefore we gladly share it upon request.

The wet surface temperature, $T_{w s}$, can be approximated by the MODIS temperature values over shallow open water surfaces with negligible mass/energy transfer in the form of inand outflow rates, as was done by Szilagyi and Jozsa (2009a). However, this may not always be possible when e.g., the watershed in question or its proximity does not have lakes or wet meadows large enough to clearly show up in the roughly 1$\mathrm{km}$ resolution MODIS image as a separate cell, as is the case with the present study catchment. Naturally, an open water body (mostly due to its albedo) would have a $Q_{n}$ term different from the rest of the watershed, but this effect may not be detrimental as the results of Szilagyi and Jozsa (2009a) indicate. In the lack of clearly identifiable open water surfaces in the MODIS images, the wet surface temperature can be es- timated as the mean of the lowest $T_{s}$ values, $\left\langle T_{w s}\right\rangle$, within the study region since these values can be expected to correspond to the wettest condition in the area. Taking a mean of several values rather than picking the lowest $T_{s}$ value is recommended because some cloud effects may still be present even in the monthly averaged cell values. In our study catchment, the Elkhorn River in north-eastern Nebraska, USA, we set this number to be $\sim 100$ out of the more than 15 thousand MODIS cells comprising the catchment.

Disaggregation of the watershed-representative monthly ET values into MODIS cell values were guided by the following consideration. As it was stated above, Eq. (1) is valid for extensive areas that provide for negligible energy advection therefore its application on a cell-by-cell basis is not attempted here. Rather, a linear transformation approach of ET vs. $T_{s}$ is sought for on the premise that the colder a MODIS cell the larger is the cooling effect of ET, thus ET itself. This requires that $Q_{n}$ is roughly constant among the cells (i.e. the albedo of the cells is not very different, and slope aspects are random within a cell). The linear transformation requires two points to be specified in the ET- $T_{S}$ plane, one of them is the $\left(<T_{s}>,<\mathrm{ET}>\right)$ value pair. The other point is represented by $\left\langle T_{w s}>\right.$ and the corresponding wet-environment ET rate, $\mathrm{ET}_{w}$, which is generally specified by the PriestleyTaylor equation (1972) as

$\mathrm{ET}_{w}=\alpha \Delta(\Delta+\gamma)^{-1} Q_{n}$

where $\alpha[-]$ is the Priestley-Taylor parameter, the most typical value being 1.26 (employed here) within a frequently cited range of 1.2-1.3 (Brutsaert, 2005), and $\Delta$ $\left[\mathrm{ML}^{-1} T^{-2} \mathrm{~K}^{-1}\right]$ is the slope of the saturated vapor pressure curve at the mean air temperature, $T_{d}$. Thus the $\left(<T_{s}>\right.$, $<\mathrm{ET}>)$ and $\left(<T_{w s}>, \mathrm{ET}_{w}\right)$ value pairs define the necessary linear transformation of the cell $T_{s}$ values into ET rates on a monthly basis. Note that the roughly $1-\mathrm{km}$ spatial resolution of the MODIS data is large enough so that the wetenvironment ET should not be specified by the Penman equation which works well for small wet and open water surfaces only. At the same time the $1-\mathrm{km}$ scale may not be sufficiently large so that the resulting ET from these wet cells could automatically be considered as the wet-environment ET rate. Therefore the true wet cell ET rates are expected to lie between the values specified by the Penman and PriestleyTaylor equation. However, when the Penman equation was used for our study watershed in place of the Priestley-Taylor equation, many $T_{S}$ cell values transformed into negative cell ET values in several months confirming that the Penman rate is indeed too high for the $1-\mathrm{km}$ resolution. The same problem has not practically occurred with the Priestley-Taylor equation, indicating that the true wet-cell ET rate must indeed be close to this value. The linear transformation has the distinct advantage that it preserves the mean, thus ensuring that the spatial mean of the ET cell values is the same as $<\mathrm{ET}>$ as long as the number of negative cell ET values (and the 


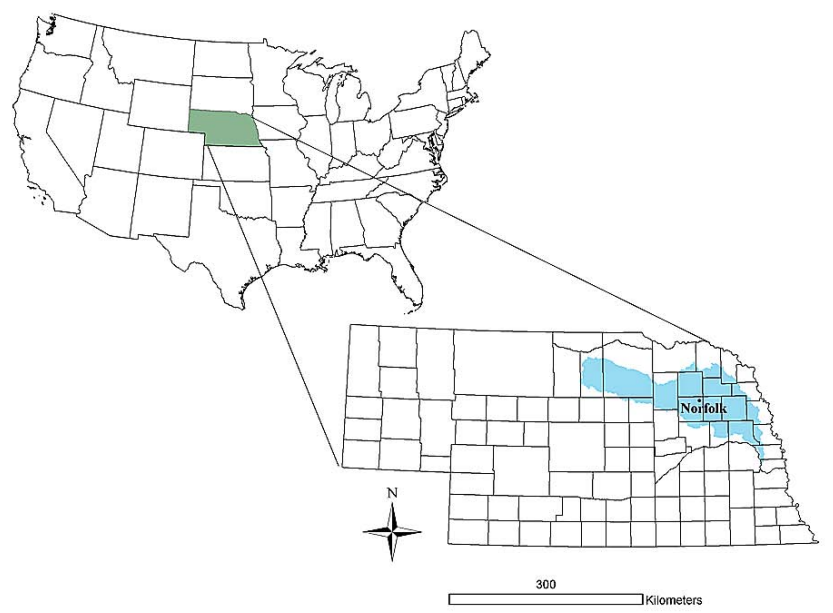

Fig. 1. Location of the Elkhorn River watershed and the climate station within.

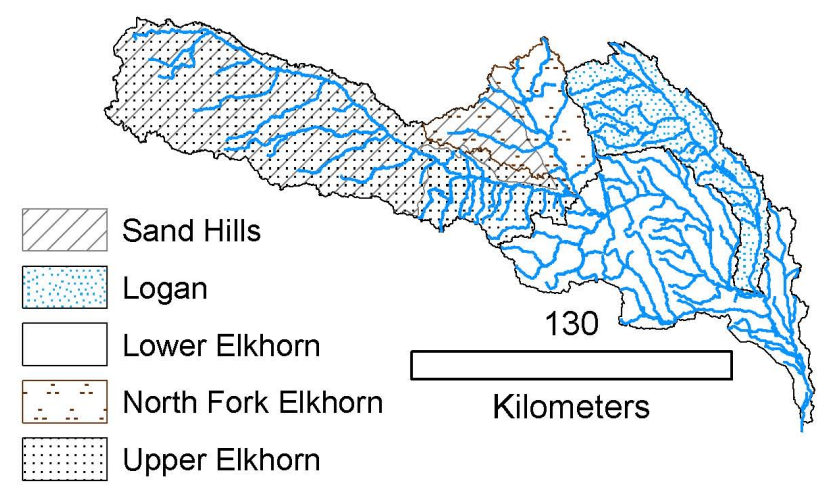

Fig. 2. Stream network and sub-catchments of the Elkhorn. Also shown is the extent of the Sand Hills within the catchment.

necessary replacement of the negative values with zeros) is negligible. In the rare occurrence when the surface temperature value of a cell is smaller than $\left\langle T_{w s}\right\rangle$, we limited the corresponding ET rate to $\mathrm{ET}_{w}$, out of consideration that this ought to be the maximum achievable ET rate of the MODIS cell in the given month, thus the effect of any potential cloud contamination still present in the MODIS data on ET having been reduced.

\section{Model application and results}

\subsection{Study watershed description}

The above model was tested on the Elkhorn River watershed in north-eastern Nebraska (Fig. 1). The Elkhorn catchment is a medium-sized watershed having an area of $18100 \mathrm{~km}^{2}$. The climate data the model requires is from Norfolk, just in the middle of the watershed (Fig. 1) at an elevation of $471 \mathrm{~m}$. The only model input, percent possible sunshine, not

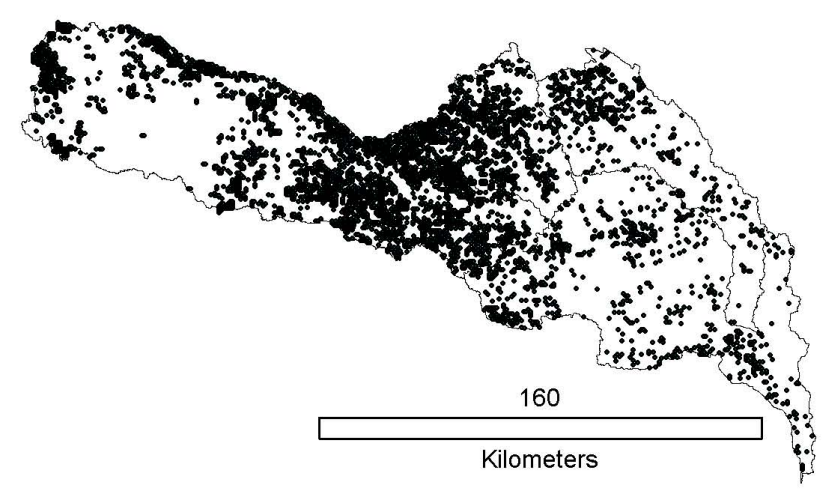

Fig. 3. Distribution of the roughly 4700 registered center-pivots within the catchment.

available in Norfolk came from Sioux Falls, South Dakota, about $160 \mathrm{~km}$ north of Norfolk. Catchment climate is continental, with warm summers (July mean air temperature is about $23^{\circ} \mathrm{C}$ ) and cold winters (January mean air temperature is around $-3^{\circ} \mathrm{C}$ ), with a long-term mean annual precipitation of about $650 \mathrm{~mm}$ out of which about $350 \mathrm{~mm}$ falls in the growing season (NDNR, 2006). The wettest month is June, with about $110 \mathrm{~mm}$ of precipitation, and the driest is January with less than $15 \mathrm{~mm}$. Mean relative humidity is typically in the range of $65-75 \%$, accompanied with average sustained winds of about $3-4 \mathrm{~ms}^{-1}$ at $2 \mathrm{~m}$. Percent possible sunshine in the summer is typically about $70 \%$.

The watershed, being situated in the Great Plains has minor relief changes, most of it occurring in the western, Sand Hills portion of it (Fig. 2). While this part is made up of eolian sand, the rest of the watershed sits predominantly on glacial till deposits. Depth to the groundwater varies widely over the watershed from several meters to more than $70 \mathrm{~m}$ and so does the saturated thickness, from 0 to almost $300 \mathrm{~m}$ (NDNR, 2006). The specific yield of the water-bearing unconfined aquifer is within the range of 5 to $20 \%$ (NDNR, 2006).

The dominant land-cover is range-land grass in the Sand Hills portion of the watershed, while the rest of the catchment is predominantly irrigated crop, mostly corn and soybean (Dappen et al., 2007). About $4500 \mathrm{~km}^{2}$ (25\% of the drainage area) is irrigated within the watershed from around 8400 registered wells (NDNR, 2006), out of which, circa 4700 are center pivots (CSD, 1996). Figure 3 displays the distribution of the center pivot irrigation systems.

\subsection{Results by the WSE-based method}

The MODIS data available online start with the year of 2000 , therefore the modeling period was chosen as 2000-2007 since not all required data were accessible for 2008. Monthly ET was modeled from March to November each year, because (a) from December till February ET is negligible due 


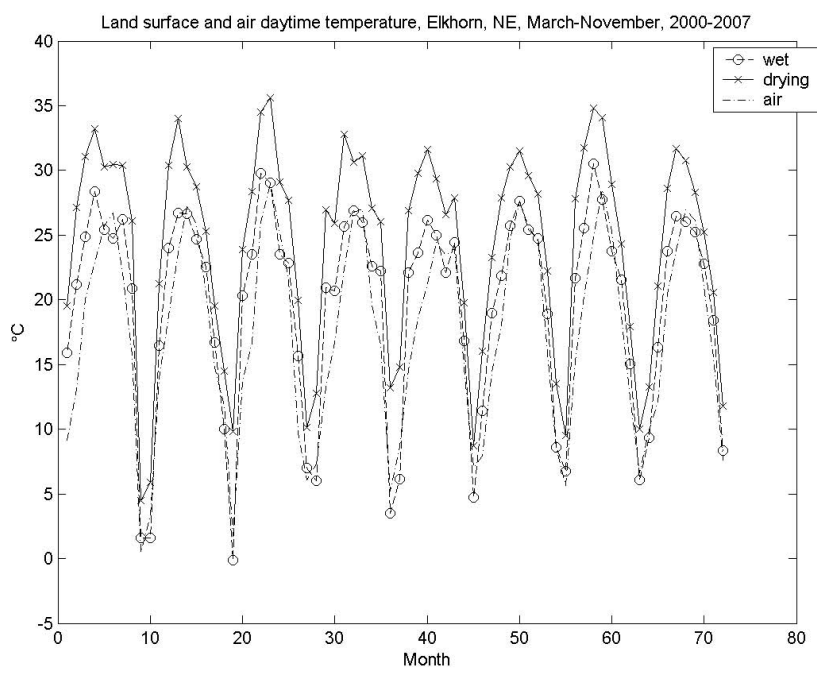

Fig. 4. Monthly watershed-representative (drying) and wetenvironment daytime land surface and air temperatures derived from MODIS and shown as a continuous record.

to the cold temperatures, and; (b) the possibly patchy snow cover (due to the snow cover's vastly different albedo from that of the land) in the winter may grossly violate the spatially constant $Q_{n}$ requirement of the model. Figure 4 displays the watershed-representative and wet-environment daytime surface temperatures by month. The mean difference between the two types of surface temperatures is about $5^{\circ} \mathrm{C}$, somewhat larger in the summer months, and smaller in the winter. The wet-environment surface temperature is typically several degrees larger than the corresponding daytime air temperature measured at $2 \mathrm{~m}$.

Figure 5 shows the watershed-representative monthly ET rates together with the wet-environment values. Note that the two ET rates were derived with different approaches, the actual ET rates with the present WSE-based method, while the wet-environment rates directly with the Priestley-Taylor equation, never employed in the WSE-based method so far, yet, it never happens that actual ET would be larger than the wet-environment ET rate estimated by the Priestley-Taylor equation, even when they are very close together in the colder months. Estimated actual ET rates are small in the cold months (less than $30 \mathrm{~mm}$ ), while they typically reach $130 \mathrm{~mm}$ in the warmest months, the largest ET rate being $170 \mathrm{~mm}$ in July, 2007, the wettest year (PRISM, 2009) within the study period, having $926 \mathrm{~mm}$ of precipitation (Fig. 8).

The present WSE-based ET estimation approach yields very similar results to the two other CR-based approaches (Fig. 6), its cold month ET values typically intermediate of the other two, the AA yielding an excessive number of months with zero ET rates, as was already reported by Szilagyi and Jozsa (2008). Figure 7 compares the different watershed-scale ET estimates on an annual basis. The Morton and AA models behaved very similarly at this temporal

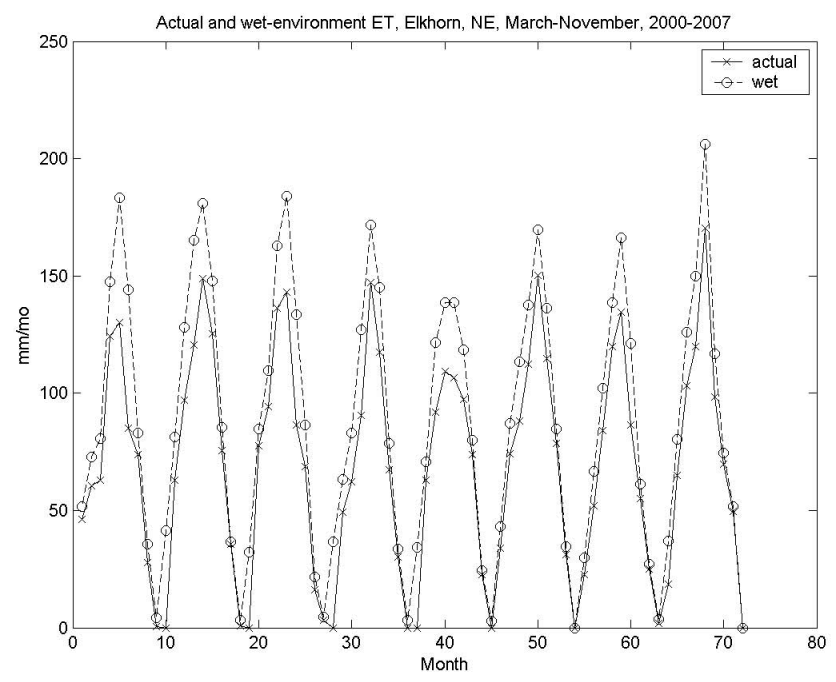

Fig. 5. Monthly estimates of the watershed-representative ET rates derived by the current WSE method. Also shown are the PriestleyTaylor wet-environment ET rates.

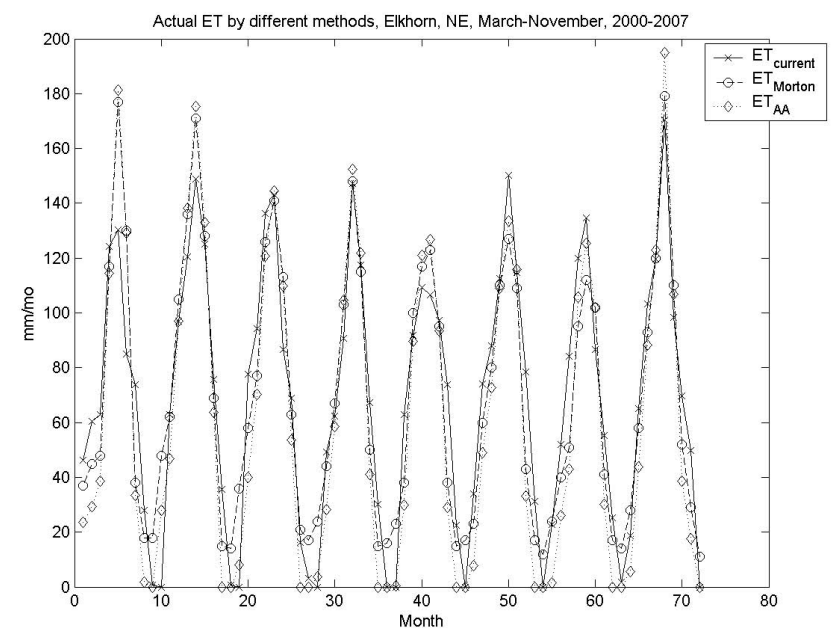

Fig. 6. Monthly estimates of the watershed-representative ET rates by different methods. Here $\alpha=1.31$ in the AA model.

scale as well, the former yielding a period-averaged mean annual ET rate of $617 \mathrm{~mm}$, while the latter $605 \mathrm{~mm}$, with a correlation coefficient of 0.98 between the two annual values. Through a simplified water balance, annual watershed ET can be estimated as the difference between precipitation and runoff (Fig. 7), resulting in a period-averaged mean of $599 \mathrm{~mm}$. The Elkhorn River at Waterloo, Nebraska has a period-averaged annual flow rate of $75 \mathrm{~mm}$ which is well within the range of the inter-annual variability of precipitation (Fig. 7), therefore the simplified water-balance ET is highly correlated (0.99) with precipitation.

At first sight the period-averaged ET rate of $624 \mathrm{~mm}$ by the present WSE-based model seems to be an overestimation 


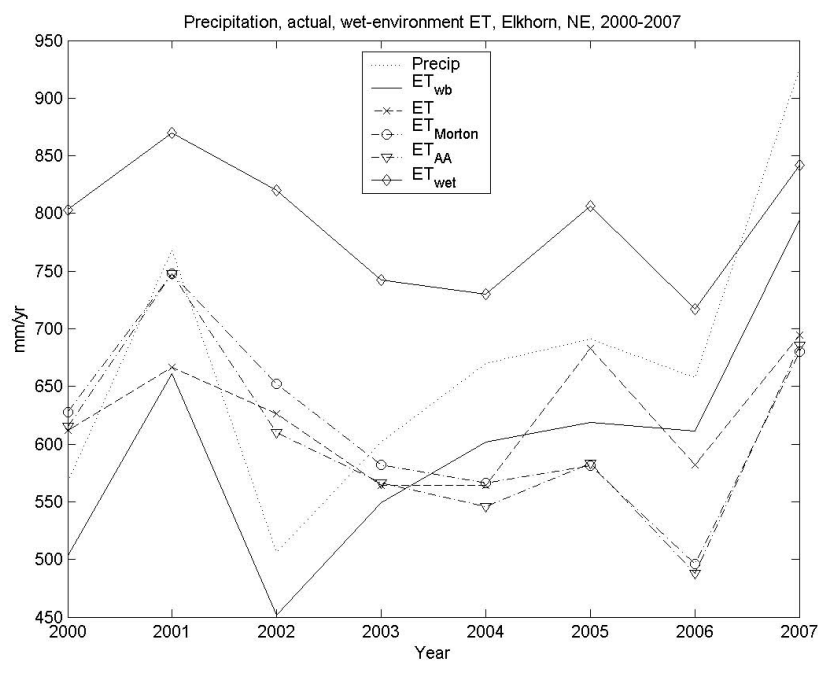

Fig. 7. Annually aggregated values of precipitation, watershedrepresentative, and wet-environment $\mathrm{ET} \mathrm{ET}_{w b}$ is the simplified water-balanced derived (i.e., the annual difference of precipitation and runoff) ET rate.

when compared to the $599 \mathrm{~mm}$ obtained from a simplified water balance. However, so far the effect of the extensive irrigation practice that takes place within the watershed, and results in $25 \%$ of the drainage area being irrigated, has not been discussed. While it is true that irrigation should not affect the period-averaged value of ET obtained by the simplified water balance purely because whatever is irrigated and thus evaporated from the watershed would show up as depletion in the runoff values, this argument holds as long as the overall water storage of the watershed is left intact over the same period. This is clearly not the case for the study watershed. The Elkhorn catchment has suffered an overall 1-1.2 m drop in groundwater levels between 2000 and 2006 (CSD, 2007). Calculating with a mean specific yield of $13 \%$, this groundwater decline translates into $130-156 \mathrm{~mm}$ of additional ET over the study period, which means an extra 16$20 \mathrm{~mm}$ annually. Thus the water-balance derived mean annual ET rate becomes about $617 \mathrm{~mm}$, which is only $1 \%$ less than what the WSE-based method predicts. From the 8 years of the study period, 2002 was the driest (PRISM, 2009) with only $506 \mathrm{~mm}$ of rain Fig. 8, and according to Fig. 7, this had to be the year when the largest drop in groundwater depletion due to irrigation must have occurred because simulated ET levels are $100-140 \mathrm{~mm}$ over the precipitation rate that year. After 2002, simulated ET levels were always smaller than precipitation.

Due to a characteristic regional west-to-east head-gradient within the unconfined groundwater across Nebraska, net groundwater inflow to the watershed is probably not zero, meaning that more water flows in across the western border of the catchment than what leaves across the eastern side, regional head gradients being somewhat gentler here. This ad-
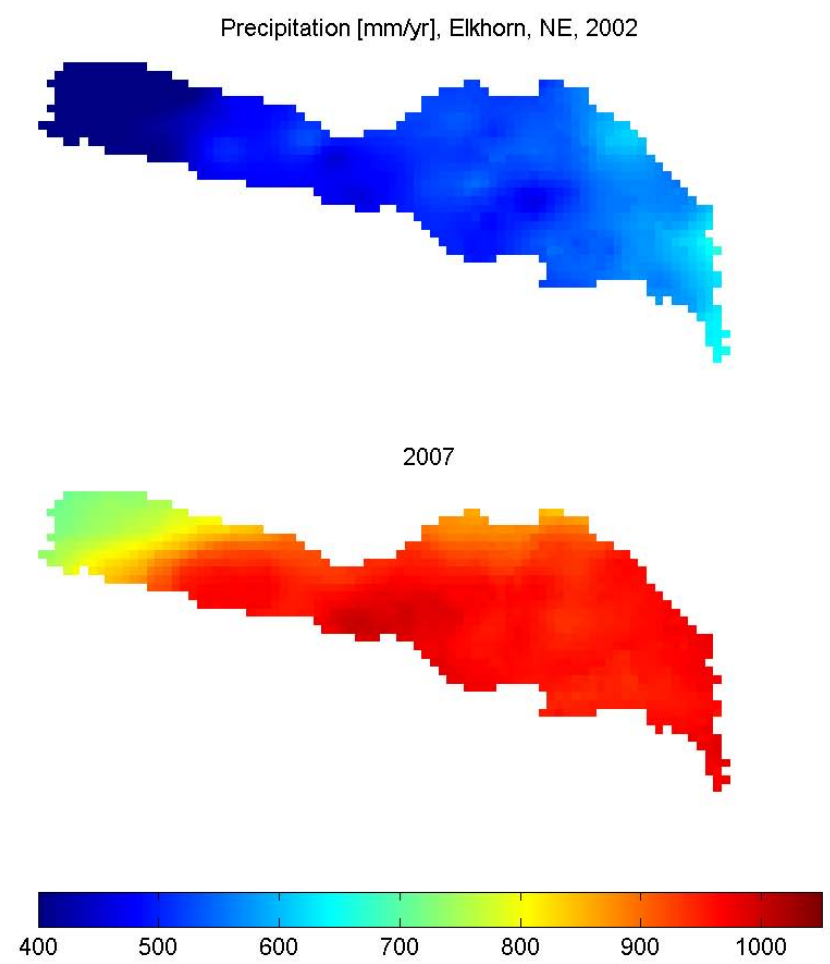

Fig. 8. Spatial distribution of the PRISM precipitation values for the driest (2002) and wettest (2007) year.

ditional source of water for ET is hard to quantify, but most probably further increases (however certainly not significantly) the water-balance derived ET value of $617 \mathrm{~mm} \mathrm{yr}^{-1}$.

\subsection{Spatially distributed surface temperature-ET trans- formation results}

There remains discussing the cell-based transformation of the surface temperature values into ET rates. Figures 9 and 10 display the distribution of the daytime surface temperature values for the driest (2002) and wettest (2007) year of the study period. The land surface temperature difference between the two years is clearly visible in June through September, just as seen in Fig. 4. In July, 2002 the western, Sand Hills, part of the watershed, with little irrigation, experienced surface temperatures well above $40^{\circ} \mathrm{C}$, while in 2007 such temperatures were absent from almost the entire watershed.

The result of the monthly linear transformations of the daytime surface temperature values into ET rates is displayed in Figs. 11 and 12, again for the two most contrasting years. In June, ET was larger in the dry year of 2002 than in the wet year of 2007, while by July it reversed. It is partly so because the month of June in 2002 had more precipitation than in 2007, while the month of July in 2002 had very little rain. Naturally, irrigation is aimed to supplement the missing rain, thus the largest contrast in ET between the two years can be 

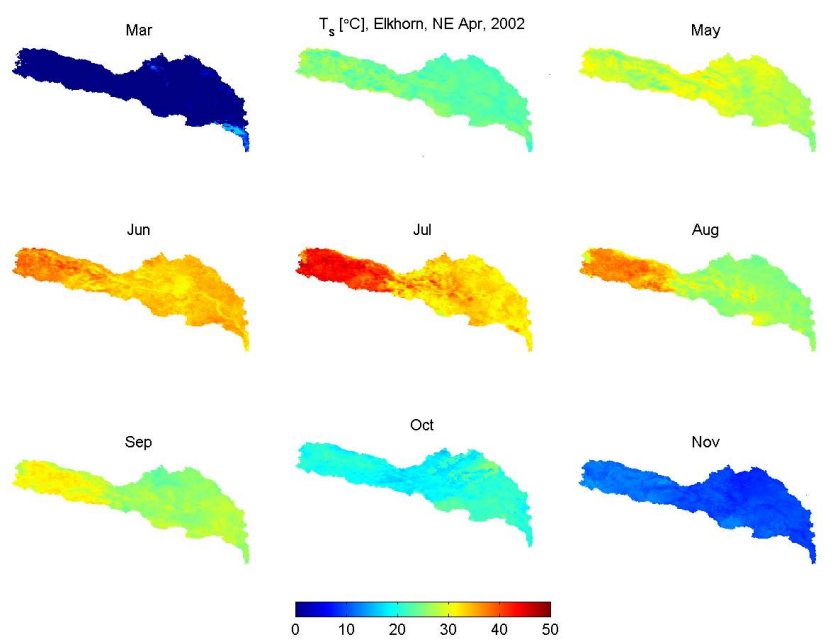

Fig. 9. Spatial distribution of the MODIS daytime land surface temperature $\left(T_{S}\right)$ values by months for 2002 .
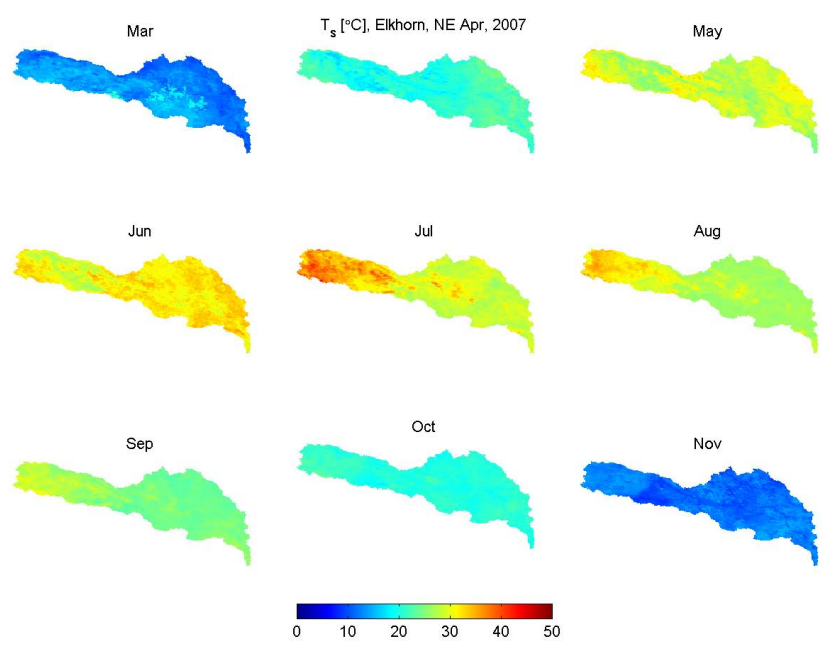

Fig. 10. Spatial distribution of the MODIS daytime land surface temperature $\left(T_{S}\right)$ values by months for 2007.

observed over the non-irrigated Sand Hills region. The ET contrast between the two years there is the largest in July and August, simply because by that time the grass in the Sand Hills depleted the available soil moisture due to the failing rains in 2002. Figure 13 displays the obtained linear transformations by months. The lower right end of each line segment corresponds to the $\left(<T_{s}>,<\mathrm{ET}>\right)$ value pair, while the upper left to the $\left(<T_{w s}>, \mathrm{ET}_{w}\right)$ pairs. Of course, during the cell-by-cell transformations the straight lines are extended to the right to reach the highest daytime land surface cell temperature observed in the month and produce the lowest ET rate in that cell within the catchment that month.
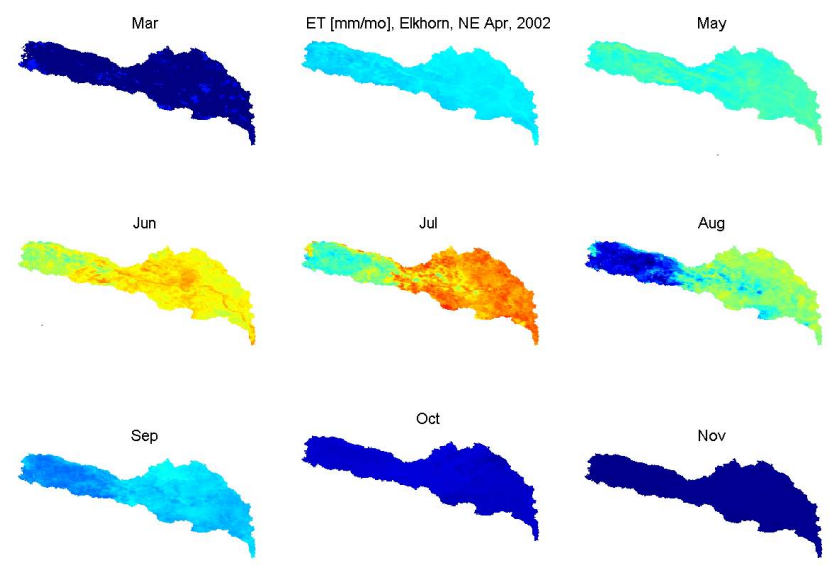

Fig. 11. Spatial distribution of the monthly ET rates for 2002, obtained by a month-by-month linear transformation of the $T_{S}$ values.
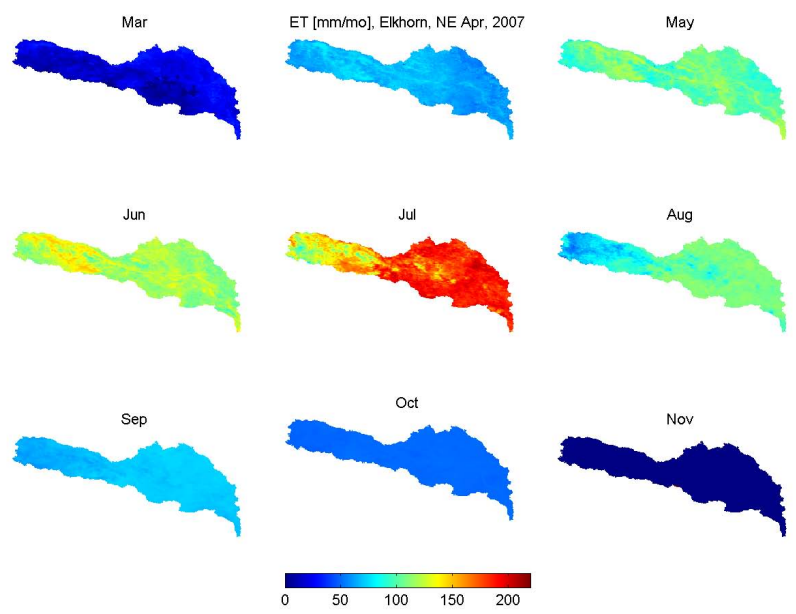

Fig. 12. Spatial distribution of the monthly ET rates for 2007, obtained by a month-by-month linear transformation of the $T_{S}$ values.

\section{Summary}

A new monthly, cell-based linear transformation of the MODIS daytime land surface temperatures into ET rates is proposed in this study. The anchor points of the monthly linear transformations are the wet-environment and the spatially averaged land surface temperatures with the corresponding wet-environment ET, given by Priestley-Taylor equation, and the spatially representative actual ET rate. The linear transformation conserves the mean, i.e., the arithmetic mean of the cell ET values is the same as the spatially-representative ET rate. The obtained linear equations are then employed over the full range of the observed daytime land surface cell temperatures within the study area. 


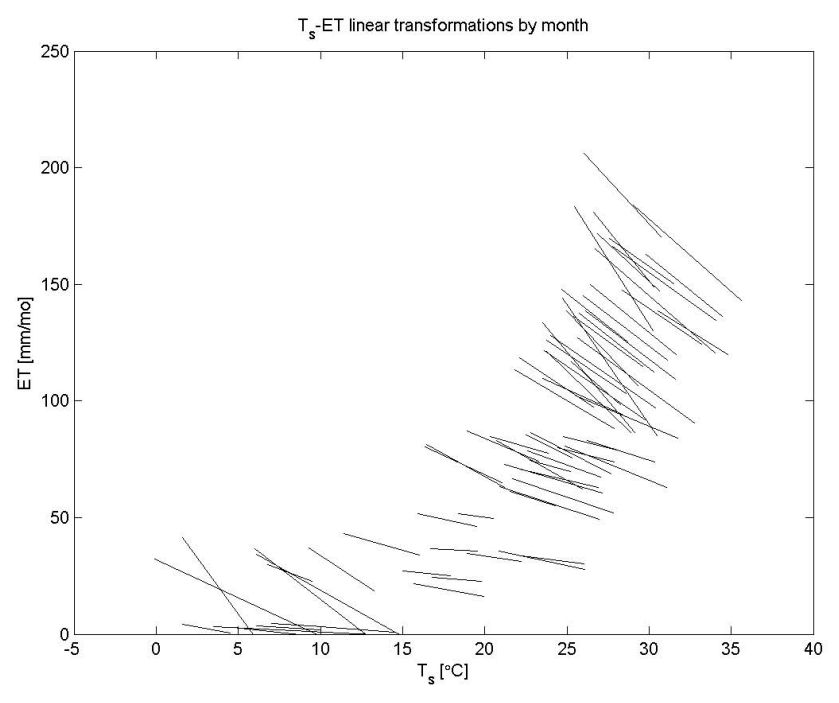

Fig. 13. Graphs of the obtained $T_{S}$-ET linear transformations for each month. The length of the horizontal projection of each line corresponds to the difference between wet-environment and watershedrepresentative land surface temperatures, the vertical projection length indicates the difference in the corresponding ET rates. During the cell-by-cell transformations each line is extended downward to reach the highest cell temperature in the given month.

The wet-environment daytime surface temperature can be obtained by the MODIS values over shallow open water bodies (or wet meadows) with negligible lateral mass/energy transfer in the form of in- and outflows, as was demonstrated by Szilagyi and Jozsa (2009a), or in the lack of them, as in this study, by the mean of a statistically significant number of cells having the lowest temperatures within the study area in the given month. This latter approach assumes the existence of wet cells each month, which may not be generally true in more arid areas where the first approach is recommended.

The spatially representative ET rate is obtainable by the simultaneous application of the Bowen ratio and the analytical solution, called wet-surface equation (Szilagyi and Jozsa, 2009a), of the coupled 2-D turbulent heat and moisture transport equations under restrictive conditions, namely, minimal advection, constant net energy at the surface, as well as unchanging atmospheric conditions over the applied time-step, all these the requirements of the existing ComplementaryRelationship-based ET estimation methods, such as the Advection Aridity model of Brutsaert and Stricker (1979) or Morton's (1985) WREVAP program.

The proposed method does not have any parameters to calibrate. However, in future applications it may be necessary to adjust the value of the Priestley-Taylor parameter in the wetenvironment ET equation. Here the most widely accepted value of 1.26 was used for the current ET estimation algorithm. Also, the required number of statistically significant wet cells (in the lack of extensive shallow water bodies or wet meadows) may vary from study to study, based mostly
Table 1. Sensitivity of the watershed-representative, periodaveraged annual ET rate to the number of wet cells chosen for averaging. The study-employed values are in bold.

\begin{tabular}{llllllll}
\hline \% of total cells & 0.1 & 0.3 & 0.5 & $\mathbf{0 . 6}$ & 0.7 & 0.9 & 1.1 \\
\hline \# of cells & 16 & 47 & 79 & $\mathbf{9 4}$ & 110 & 141 & 173 \\
\hline ET $\left(\mathrm{mm} \mathrm{yr}^{-1}\right)$ & 622 & 637 & 629 & $\mathbf{6 2 4}$ & 627 & 632 & 636 \\
\hline
\end{tabular}

on how many of the cells are actually wet. In this study we specified this number a constant, i.e. $0.6 \%$ of the total number of cells within the study watershed, resulting in about 100 (94 to be exact) cells. In more humid watersheds this number may be higher, while in more arid ones lower. The overall ET estimates in our case are only slightly sensitive to the exact value of this number within the $0.1 \%-1.1 \%$ range (Table 1). For additional sensitivity analysis of the variables in Eq. 1, see Szilagyi and Jozsa (2009a).

A convenient way of checking the correctness of the model is making sure that (a) the spatially- or watershedrepresentative ET rate is always smaller than the corresponding wet-environment ET value; (b) the number of cells with negative estimated ET rates is minimal.

The present model has been applied over the Elkhorn watershed in north-eastern Nebraska, and at the watershed-scale produced very similar results to other Complementary Relationship based models. Over the 2000-2007 study period the present model yielded a period-averaged mean annual ET rate $(624 \mathrm{~mm})$ only $1 \%$ more than the water-balance calculated value of $617 \mathrm{~mm}$. With the help of the spatially distributed ET estimates it was possible to detect the vastly differing moisture dynamics of the grass-covered range-lands of the Sand Hills in the western part of the Elkhorn watershed from that of the rest of the catchment covered by intensively irrigated corn and soybean fields.

The present method is expected to work best on a time-step larger than a week therefore the 8-day composited MODIS images are almost ideally suited for the present method. Its input data requirement is very modest, beside the daytime land surface temperatures, only daily mean and maximum air temperature, humidity and percent possible sunshine (or incident global radiation) are needed. The model currently employs Morton's algorithm (1985) for the net surface radiation value in the Priestley-Taylor equation. The method should not be used near sudden discontinuities in land-surface properties (Morton, 1983, 1985) such as the sea-land interface because there the minimal advection requirement of the Complementary Relationship is seriously violated since in such areas the land and air moisture dynamics are mostly decoupled (Szilagyi and Jozsa, 2008). 
Acknowledgements. This work has partially been supported by the European Union's Climate Change and Variability: Impact on Central and Eastern Europe (CLAVIER) FP6 project. The authors are grateful for the anonymous reviewers whose comments and suggestions resulted in an improved manuscript.

Edited by: A. Gelfan

\section{References}

Bouchet, R. J.: Evapotranspiration reelle, evapotranspiration potentielle, et production agricole, Ann. Agron., 14, 543-824, 1963.

Brutsaert, W.: Hydrology, an Introduction, Cambridge University Press, Cambridge, UK, 2005.

Brutsaert, W. and Stricker, H.: An advection-aridity approach to estimate actual regional evapotranspiration, Water Resour. Res., 15, 443-449, 1979.

Conservation and Survey Division (CSD): Center pivot irrigation systems, http://snr.unl.edu/Data/NebrGIS.asp\# CenterPivotIrrigation, 1996.

Conservation and Survey Division (CSD): Groundwater level changes in Nebraska-spring 2000 to spring 2006, http://snr.unl. edu/Data/NebrGIS.asp\#GroundwaterSpr2000Spr2006, 2007.

Courault, D., Seguin, B., and Olioso, A.: Review on estimation of evapotranspiration from remote sensing data: From empirical to numerical modeling approaches, Irrig. Drain. Syst., 19(3-4), 223-249, 2005.

Dappen, P. J., Merchant, W., Ratcliffe, I., and Robbins, C.: Delineation of 2005 Land Use Patterns For The State of Nebraska. Lincoln, NE: Center for Advanced Land Management Information Technologies, School of Natural Resources, University of Nebraska-Lincoln, 2007.

Gowda, P. H., Chavez, J. L., Colaizzi, P. D., Evett, S. R., Howell, T. A., and Tolk, J. A.: ET mapping for agricultural water management: present status and challenges, Irrig. Sci., 26, 223-237, 2008 .
Laikhtman, D. L.: Physics of the Boundary Layer of the Atmosphere, Sivan Press, Israel, 1964.

Maidment, D. R.: Handbook of Hydrology, McGraw-Hill, New York, 1993.

Morton, F. I.: Operational estimates of areal evapotranspiration and their significance to the science and practice of hydrology, J. Hydrol., 66, 1-76, 1983.

Morton, F. I., Ricard, F., and Fogarasi, S.: Operational estimates of areal evapotranspiration and lake evaporation - Program WREVAP, National Hydrological Research Institute Paper \#24, Ottawa, Ontario, Canada, 1985.

Nebraska Department of Natural Resources (NDNR): 2006 Annual evaluation of availability of hydrologically connected water supply, http://www.dnr.state.ne.us/LB962/AnnualReport, 2006.

Parlange, M. and Katul, G.: An Advection-Aridity Evaporation Model, Water Resour. Res., 28(1), 127-132, 1992.

Penman, H. L.: Natural evaporation from open water, bare soil, and grass, Proc. Royal Soc London, A193, 120-146, 1948.

Priestley, C. H. B. and Taylor, R. J.: On the assessment of surface heat flux and evaporation using large-scale parameters, Mon. Weather Rev., 100, 81-92, 1972.

PRISM Group, Oregon State University: http://www.prismclimate. org, created 4 February 2004, 2009.

Szilagyi, J. and Jozsa, J.: New findings about the complementary relationship-based evaporation estimation methods, J. Hydrol., 354, 171-186, 2008.

Szilagyi, J. and Jozsa, J.: An evaporation estimation method based on the coupled 2-D turbulent heat and vapor transport equations, J. Geophys. Res., 114, D06101, doi:10.1029/2008JD010772, 2009a.

Szilagyi J. and Jozsa, J.: Analytical solution of the coupled 2-D turbulent heat and vapor transport equations and the complementary relationship of evaporation, J. Hydrol., doi:10.1016/j.jhydrol.03.035, in press, 2009b.

Yeh, G. T. and Brutsaert, B.: A solution for simultaneous turbulent heat and vapor transfer between a water surface and the atmosphere, Bound.-Lay. Meteor., 2, 64-82, 1971. 